Article

\title{
Beneficial Effects of the Consumption of Hot-Water Extracts of Thinned Immature Mangos (Mangifera indica "Irwin") on the Hypertriglyceridemia of Apolipoprotein E-Deficient Mice
}

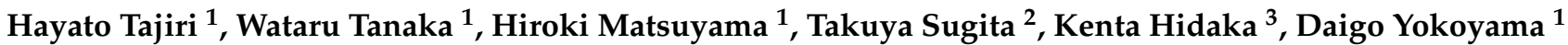 \\ and Hiroyuki Sakakibara ${ }^{1, * \mathbb{D}}$ \\ 1 Graduate School of Agriculture, University of Miyazaki, 1-1 Gakuen-Kibanadai Nishi, \\ Miyazaki 889-2192, Japan; gc16021@student.miyazaki-u.ac.jp (H.T.); gc14026@student.miyazaki-u.ac.jp (W.T.); \\ nb21008@student.miyazaki-u.ac.jp (H.M.); yokoyama.d@cc.miyazaki-u.ac.jp (D.Y.) \\ 2 Agricultural Administration Section, Saito 881-8501, Japan; sugitat@city.saito.lg.jp \\ 3 Star-Fruits Company, Ltd., Saito 881-0104, Japan; kentahidaka002@gmail.com \\ * Correspondence: hiroyuki@cc.miyazaki-u.ac.jp; Tel.: +81-985-58-7213
}

Citation: Tajiri, H.; Tanaka, W.; Matsuyama, H.; Sugita, T.; Hidaka,

K.; Yokoyama, D.; Sakakibara, H.

Beneficial Effects of the Consumption of Hot-Water Extracts of Thinned Immature Mangos (Mangifera indica "Irwin") on the Hypertriglyceridemia of Apolipoprotein E-Deficient Mice. Metabolites 2022, 12, 116. https:// doi.org/10.3390/metabo12020116

Academic Editors: Bungo Shirouchi and Masashi Inafuku

Received: 19 December 2021

Accepted: 21 January 2022

Published: 25 January 2022

Publisher's Note: MDPI stays neutral with regard to jurisdictional claims in published maps and institutional affiliations.

Copyright: () 2022 by the authors Licensee MDPI, Basel, Switzerland. This article is an open access article distributed under the terms and conditions of the Creative Commons Attribution (CC BY) license (https:// creativecommons.org/licenses/by/ $4.0 /)$.

\begin{abstract}
The thinned immature fruit of the mango tree (Mangifera indica "Irwin") are regarded as waste products. In this study, we evaluated the effects of daily consumption of a hot-water extract of thinned immature mango fruits (TIMEx) on the dyslipidemia of apolipoprotein E-deficient ( $\mathrm{ApoE}^{-/-}$) mice. ApoE ${ }^{-/-}$mice and wild-type BALB/c mice were fed a $20 \%$ fat diet containing $0 \%, 0.1 \%$, or $1.0 \%$ TIMEx for 8 weeks. Their body mass, food intake, and water consumption were unaffected by the TIMEx. The 1.0\% TIMEx supplementation significantly reduced serum triglyceride, but not total cholesterol concentration. This effect was significant in $\mathrm{ApoE}^{-/-}$mice, but less marked under normal conditions in wild-type mice. In addition, the circulating concentrations of three hormones that regulate metabolism, resistin, leptin, and glucose-dependent insulinotropic polypeptide, were reduced by TIMEx consumption, which may be involved in its effect to prevent hypertriglyceridemia. However, none of the concentrations of TIMEx reduced the size of atherosclerotic plaque lesions. In conclusion, daily consumption of TIMEx ameliorates hypertriglyceridemia but not hypercholesterolemia in genetically predisposed mice.
\end{abstract}

Keywords: apolipoprotein E-deficient mice; dyslipidemia; hypertriglyceridemia; thinned immature mango; triglyceride

\section{Introduction}

Dyslipidemia is characterized by a spectrum of quantitative and qualitative changes in lipids and lipoproteins [1]. The most common pattern of lipid abnormalities includes hypertriglyceridemia and hypercholesterolemia. Dyslipidemia is globally recognized as one of the most important risk factors for the development and complications of atherosclerotic cardiovascular disease, which is a major cause of morbidity and mortality [2-4]. One of the causes of dyslipidemia is recognized as a disturbed diet pattern. The diets of many populations around the world have moved toward a Western-style diet, which contains high proportions of fat and refined sugars, relatively low proportions of complex carbohydrates and fiber, and a low content of fruit and vegetables [5]. Therefore, modification of the diet is essential for the prevention of dyslipidemia.

Mango (Mangifera indica L.) is one of the most popular tropical fruits in the world. Global mango production was $\sim 40$ million tons in 2018, which represented an increase of $2.8 \%$ from 2017 [6]. The fruit pulp is characterized by density and sweetness, but also has high nutritional value, because of the presence of vitamins, dietary fiber, and various polyphenols [7-10]. Hence, the mango has been referred to as the "King of Fruits" [11].

For many fruits, including the mango, size is a major determinant of yield and marketability $[12,13]$. Most of the fruits are thinned out during their immature stage, which 
increases the size and quality of the remaining fruits [14]. In the mango production industry, the immature fruits, which are green and weigh $<10 \mathrm{~g}$, are harvested, and such fruits subsequently soften, but do not develop a pleasing flavor, and therefore cannot be sold [15]. Therefore, most thinned immature mango fruits are disposed of.

Our group has recently focused on the thinned immature fruits of the Irwin mango cultivar (Mangifera indica "Irwin") as an unused natural resource. We conducted a 90-day toxicity study using rat model to evaluate the safety of a hot-water extract of thinned immature mango fruit (TIMEx), because there was insufficient published information concerning the safety and dietary characteristics of TIMEx to enable their dietary use. We found that 90 days of TIMEx administration was well tolerated by rats of both sexes and that it caused no significant changes in their condition, hematology, blood chemistry, or urine composition [16], and the No Observed Adverse Effect Level (NOAEL) for TIMEx in rats was calculated to be $2500 \mathrm{mg} / \mathrm{kg} /$ day. During the study, we also found that TIMEx reduced the serum triglyceride concentration; 90 days of administrating $2500 \mathrm{mg} / \mathrm{kg} /$ day TIMEx resulted in decreases in serum triglyceride concentration of $16.8 \%$ in male rats and $11.5 \%$ in female rats, by comparison with vehicle controls [16]. These results led us to formulate the hypothesis that TIMEx might prevent dyslipidemia, especially hypertriglyceridemia.

In this study, we evaluated the effects of the daily consumption of TIMEx on the dyslipidemia of atherosclerotic mice (apolipoprotein E-deficient mice; $\mathrm{ApoE}^{-/-}$mice) that were consuming a $20 \%$ fat-containing diet. Additionally, we analyzed the secretion of major metabolic hormones including resistin, leptin, glucose-dependent insulinotropic polypeptide (GIP), insulin, amylin and glucagon-like peptide-1 (GLP-1), which regulate lipid homeostasis [17-20], in order to speculate the mechanisms involved.

\section{Results}

\subsection{Growth Parameters and Organ Masses}

The consumption of $0.1 \%$ and $1.0 \%$ TIMEx containing diet for 8 weeks did not affect the body mass gain, food intake, or water intake of either wild-type or $\mathrm{ApoE}^{-/}$mice (Table 1). The liver mass of wild-type mice that consumed 1.0\% TIMEx diet increased, but the consumption of $0.1 \%$ TIMEx did not have this effect (Table 1). This effect did not occur in the $\mathrm{ApoE}^{-/-}$mice. The masses of the kidney, spleen, visceral fat, and brown fat of both groups of mice were unaffected by TIMEx consumption.

\subsection{Serum Lipid Concentrations}

After 8 weeks consumption, the serum triglyceride and total cholesterol concentrations of the $\mathrm{ApoE}^{-/-}$mice were much higher than those of wild-type mice fed the $0 \%$ TIMEx diet $(446 \pm 44 \mathrm{mg} / \mathrm{dL}$ vs. $57 \pm 7 \mathrm{mg} / \mathrm{dL}$ for triglyceride; $578 \pm 26 \mathrm{mg} / \mathrm{dL}$ vs. $114 \pm 5 \mathrm{mg} / \mathrm{dL}$ for total cholesterol) (Figure 1a,b). The serum triglyceride concentration was dose-dependently reduced and was significantly affected in the 1.0\% TIMEx group. However, this effect was not observed in the wild-type mice $(57 \pm 7 \mathrm{mg} / \mathrm{dL}$ for $0 \%$ TIMEx; $45 \pm 10 \mathrm{mg} / \mathrm{dL}$ for $0.1 \%$ TIMEx; $65 \pm 5 \mathrm{mg} / \mathrm{dL}$ for $1.0 \%$ TIMEx). On the other hand, TIMEx supplementation did not affect serum total cholesterol, glucose, albumin concentrations, nor the serum aspartate aminotransferase (AST), alanine aminotransferase (ALT) activities of the mice groups (Figure 1c-f).

\subsection{Hepatic Lipid Concentrations}

The hepatic concentrations of triglycerides, total cholesterol, and phospholipids were measured. The hepatic triglyceride concentration was much higher in the $\mathrm{ApoE}^{-1-}$ mice than in wild-type mice fed the $0 \%$ TIMEx diet $(14.3 \pm 0.4 \mathrm{vs} .7 .4 \pm 0.8 \mathrm{mg} / \mathrm{g}$ ) (Figure 2a). TIMEx supplementation tended to reduce triglyceride accumulation, but not significantly. There were no differences in the hepatic total cholesterol or phospholipid concentrations among the groups (Figure $2 b, c$ ). 
Table 1. Effects of the consumption of a hot-water extract of thinned immature mango on the growth parameters and organ masses of the mice.

\begin{tabular}{|c|c|c|c|c|c|c|}
\hline \multirow{2}{*}{ Measurements } & \multicolumn{3}{|c|}{ Wild-Type $(n=6)$} & \multicolumn{3}{|c|}{$\operatorname{ApoE}^{-1-}(n=9)$} \\
\hline & 0\% TIMEx & $0.1 \%$ TIMEx & $1.0 \%$ TIMEx & 0\% TIMEx & 0.1\% TIMEX & 1.0\% TIMEX \\
\hline \multicolumn{7}{|l|}{ Body mass (g) } \\
\hline week 0 & $23.9 \pm 0.4$ & $23.8 \pm 0.4$ & $23.9 \pm 0.6$ & $23.5 \pm 0.5$ & $23.2 \pm 0.6$ & $23.4 \pm 0.3$ \\
\hline week 8 & $29.3 \pm 0.5$ & $28.1 \pm 0.7$ & $29.0 \pm 0.5$ & $28.2 \pm 2.3$ & $28.4 \pm 0.9$ & $28.1 \pm 0.8$ \\
\hline Body mass gain $(\mathrm{g})$ & $5.4 \pm 0.4$ & $4.2 \pm 0.5$ & $5.1 \pm 0.4$ & $4.7 \pm 0.7$ & $5.3 \pm 0.6$ & $4.7 \pm 0.6$ \\
\hline $\begin{array}{l}\text { Food intake } \\
\text { (kcal/mouse/day) }\end{array}$ & 12.1 & 12.0 & 13.7 & $12.9 \pm 0.6$ & $13.0 \pm 0.3$ & $14.2 \pm 0.5$ \\
\hline TIMEx & & & & & & \\
\hline $\begin{array}{l}\text { consumption } \\
\text { (mg/mouse/day) }\end{array}$ & - & 2.6 & 27.7 & - & $2.8 \pm 0.2$ & $28.6 \pm 1.0$ \\
\hline $\begin{array}{l}\text { Water intake } \\
\text { (g/mouse/day) }\end{array}$ & 2.9 & 2.4 & 2.7 & $2.7 \pm 0.3$ & $2.8 \pm 0.3$ & $3.3 \pm 0.7$ \\
\hline \multicolumn{7}{|c|}{ Relative organ masses (g/100 g body mass) } \\
\hline liver & $3.75 \pm 0.09$ & $3.58 \pm 0.19$ & $4.20 \pm 0.08^{*}$ & $4.88 \pm 0.13$ & $4.73 \pm 0.10$ & $4.31 \pm 0.24$ \\
\hline kidney & $1.21 \pm 0.222$ & $1.40 \pm 0.04$ & $1.31 \pm 0.04$ & $1.43 \pm 0.03$ & $1.38 \pm 0.08$ & $1.41 \pm 0.05$ \\
\hline spleen & $0.37 \pm 0.07$ & $0.46 \pm 0.02$ & $0.43 \pm 0.02$ & $0.46 \pm 0.02$ & $0.44 \pm 0.01$ & $0.41 \pm 0.01$ \\
\hline visceral fat & $1.14 \pm 0.23$ & $1.02 \pm 0.14$ & $1.49 \pm 0.16$ & $2.08 \pm 0.21$ & $2.63 \pm 0.36$ & $2.22 \pm 0.29$ \\
\hline brown fat & $0.26 \pm 0.05$ & $0.28 \pm 0.01$ & $0.35 \pm 0.02$ & $0.39 \pm 0.04$ & $0.39 \pm 0.03$ & $0.30 \pm 0.05$ \\
\hline
\end{tabular}

TIMEx, hot-water extract from thinned immature mangoes. The data are mean \pm SEM. ${ }^{*} p<0.05 \mathrm{vs}$. the $0 \%$ TIMEx group; Williams's multiple comparison test.

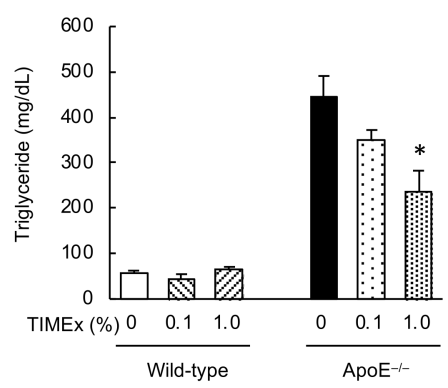

(a)

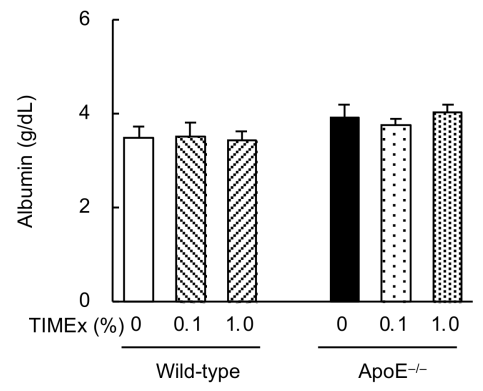

(d)

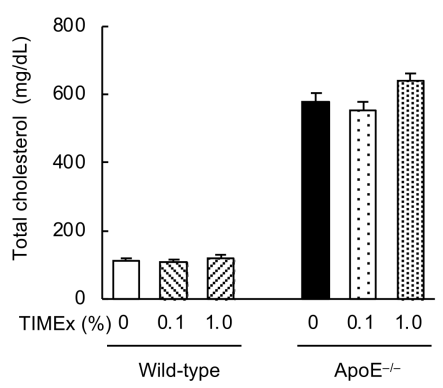

(b)

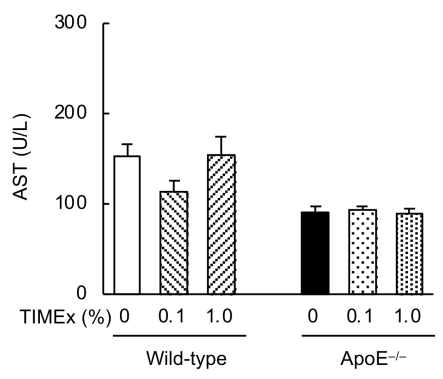

(e)

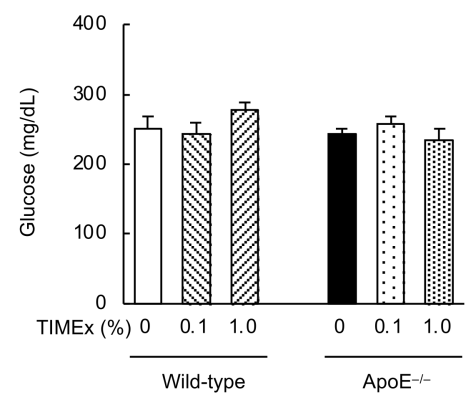

(c)

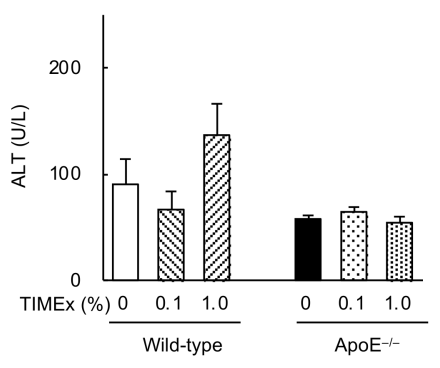

(f)

Figure 1. Effects of the consumption of a hot-water extract of thinned immature mangoes (TIMEx) on the serum biochemistry of apolipoprotein E-deficient $\left(\mathrm{ApoE}^{-/-}\right)$mice. $\mathrm{ApoE}^{-/-}$mice and wild-type BALB/c mice were divided into three diet groups: an AIN-93M-based 20\% fat diet containing 0\%, $0.1 \%$, or $1.0 \%$ TIMEx. A detailed description of the composition of each diet is shown in Table 2 . Following 8-weeks consumption of their respective diets, mice were sacrificed without fasting. The data are mean $\pm \mathrm{SEM} ; n=6$ for wild-type mice and $n=9$ for $\mathrm{ApoE}^{-/-}$mice. (a) Triglycerides, (b) total cholesterol, (c) glucose, (d) albumin, (e) aspartate transaminase (AST), and (f) alanine transaminase (ALT). ${ }^{*} p<0.05$ vs. the $0 \%$ TIMEx group; Williams's multiple comparison test. 
Table 2. Composition of the AIN-93M-based experimental diets.

\begin{tabular}{|c|c|c|c|c|}
\hline \multirow{2}{*}{ Ingredients } & \multirow{2}{*}{ AIN-93M } & \multicolumn{3}{|c|}{ Experimental Diets } \\
\hline & & 0\% TIMEX & $0.1 \%$ TIMEX & $1.0 \%$ TIMEX \\
\hline$\beta$-Cornstarch (g) & 46.6 & 30.6 & 30.5 & 29.6 \\
\hline$\alpha$-Cornstarch $(g)$ & 15.5 & 15.5 & 15.5 & 15.5 \\
\hline Casein $(g)$ & 14.0 & 14.0 & 14.0 & 14.0 \\
\hline Soybean oil (g) & 4.0 & 4.0 & 4.0 & 4.0 \\
\hline Lard $(\mathrm{g})$ & - & 16.0 & 16.0 & 16.0 \\
\hline Sucrose $(\mathrm{g})$ & 10.0 & 10.0 & 10.0 & 10.0 \\
\hline Cellulose (g) & 5.0 & 5.0 & 5.0 & 5.0 \\
\hline Vitamin mixture $(\mathrm{g})$ & 1.0 & 1.0 & 1.0 & 1.0 \\
\hline Mineral mixture (g) & 3.5 & 3.5 & 3.5 & 3.5 \\
\hline L-Cysteine (g) & 0.18 & 0.18 & 0.18 & 0.18 \\
\hline Choline bitartrate (g) & 0.25 & 0.25 & 0.25 & 0.25 \\
\hline t-Butylhydroquinone (g) & 0.0008 & 0.0008 & 0.0008 & 0.0008 \\
\hline TIMEx $(\mathrm{g})$ & - & - & 0.1 & 1.0 \\
\hline Energy (kcal/g) & 3.80 & 4.60 & 4.60 & 4.56 \\
\hline
\end{tabular}

TIMEx, hot-water extract from thinning immature mango.

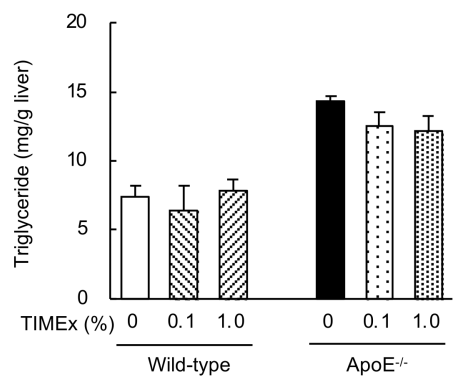

(a)

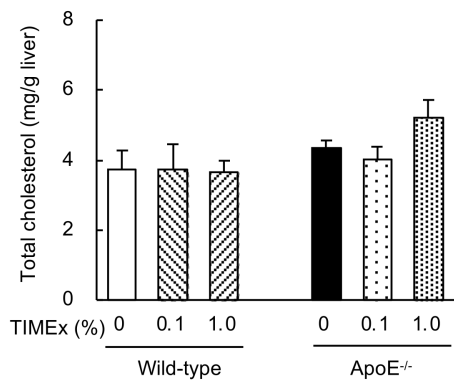

(b)

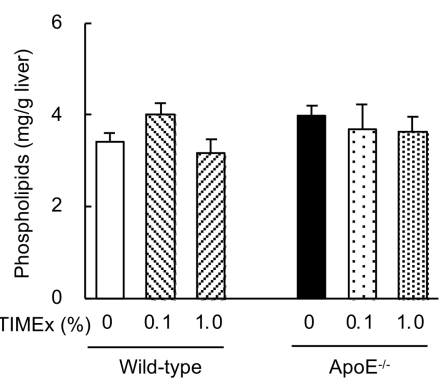

(c)

Figure 2. Effects of the consumption of a hot-water extract of thinned immature mangoes (TIMEx) on the hepatic lipid concentrations of apolipoprotein E-deficient $\left(\mathrm{ApoE}^{-/-}\right)$mice. $\mathrm{ApoE}^{-/-}$mice and wild-type BALB/c mice were divided into three diet groups: an AIN-93M-based 20\% fat diet containing $0 \%, 0.1 \%$, or $1.0 \%$ TIMEx. A detailed description of the composition of each diet is shown in Table 2. Following 8-weeks consumption of their respective diets, mice were sacrificed without fasting. The data are mean $\pm \mathrm{SEM} ; n=6$ for wild-type mice and $n=9$ for $\mathrm{ApoE}^{-/-}$mice. (a) Triglyceride, (b) total cholesterol, and (c) phospholipid concentrations. There were no significant differences versus the control group ( $0 \%$ TIMEx).

\subsection{Atherosclerotic Plaque Lesions}

We next analyzed the atherosclerotic plaque lesions in the aortas of the mice, measuring the percentage lipid deposition (Figure 3a). The atherosclerotic plaque lesions of the $0 \%$ TIMEx group $(15.8 \pm 2.2 \%)$ were similar to those of the $0.1 \%$ TIMEx group $(11.5 \pm 0.9 \%)$ and the $1.0 \%$ TIMEx group $(13.3 \pm 1.8 \%)$ after 8 weeks of consumption (Figure $3 b)$.

\subsection{Serum Hormone Concentrations}

Finally, we measured the serum concentrations of resistin, leptin, GIP, insulin, amylin, and GLP-1 in ApoE $\mathrm{E}^{-/-}$mice that had consumed $0 \%, 0.1 \%$, or $1.0 \%$ TIMEx-supplemented diets for 8 weeks (Figure 4). The resistin concentration was significantly lower in the $1.0 \%$ TIMEx group than in the $0 \%$. The leptin and GIP concentrations also tended to be lower in the $1.0 \%$ TIMEx group, but not significantly. However, the consumption of $0.1 \%$ TIMEx did not have any effects on the concentrations of these hormones. Blood levels of insulin were not affected by consumption of TIMEx. Amylin and GLP-1 levels could not be fully detected in every sample (under the detection limits of $41 \mathrm{pg} / \mathrm{mL}$ ) (data not shown). 

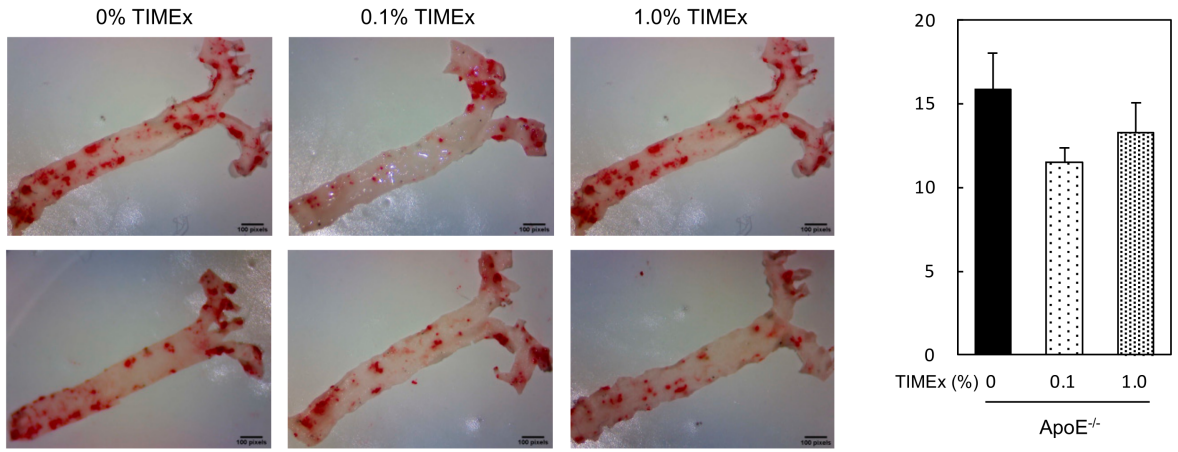

(a)

(b)

Figure 3. Effects of the consumption of a hot-water extract of thinned immature mangoes (TIMEx) on the atherosclerotic lesions of apolipoprotein E-deficient $\left(\mathrm{ApoE}^{-/-}\right)$mice. (a) Oil Red O-stained whole aortas and (b) the mean areas of the aortic atherosclerotic lesions, determined using ImageJ software (V. 1.44p, NIH, Bethesda, MD, USA). The data are mean \pm SEM; $n=9$. There were no significant differences vs. the control group (0\% TIMEx).

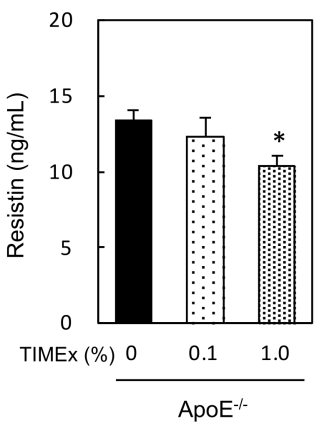

(a)

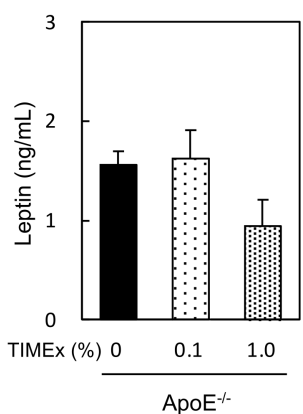

(b)

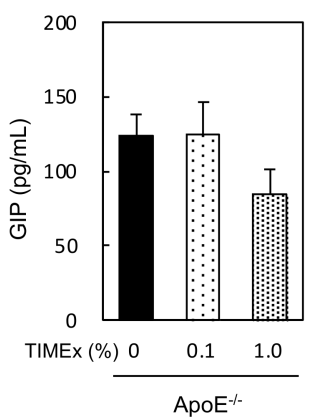

(c)

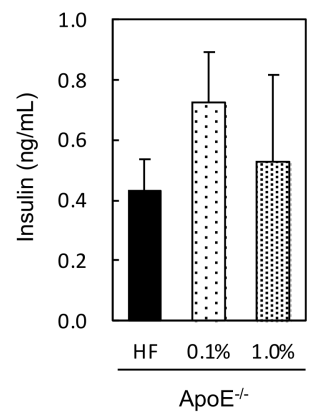

(d)

Figure 4. Effects of the consumption of a hot-water extract of thinned immature mangoes (TIMEx) on the serum concentrations of hormones in apolipoprotein E-deficient $\left(\mathrm{ApoE}^{-/-}\right)$mice. ApoE $\mathrm{Ap}^{-/-}$ mice were divided into three diet groups: an AIN-93M-based $20 \%$ fat diet containing $0 \%, 0.1 \%$, or 1.0\% TIMEx. Following 8-weeks consumption, mice were sacrificed without fasting. The data are mean \pm SEM; $n=9$. (a) Resistin, (b) leptin, and (c) glucose-dependent insulinotropic polypeptide (GIP), (d) Insulin. * $p<0.05$ vs. the control group ( $0 \%$ TIMEx); Williams's multiple comparison test.

\section{Discussion}

ApoE was initially described to be a lipid transport protein, and major ligand for low-density lipoprotein (LDL) receptors with a role in cholesterol metabolism and cardiovascular disease [21]. Hence, ApoE deficiency increases blood lipid concentrations [22]. However, the congenic ApoE deficient mice used in the present study are observed as being healthy and having a similar body mass comparing with their wild-type mice [23]. Our results are consistent with this background, because the body mass gain, daily food intake, and water consumption of the wild-type and $\mathrm{ApoE}^{-/-}$mice were similar (Table 1). Nevertheless, the lipid profiles of the mice significantly differed: The serum triglyceride and total cholesterol concentrations of the $\mathrm{ApoE}^{-/-}$mice were much higher than those of the wild-type mice (Figure 1a,b), as shown previously [24,25]. Thus, dyslipidemia developed specifically in $\mathrm{ApoE}^{-/-}$mice, despite them consuming the same $20 \%$ fat containing diet as the wild-type mice.

Daily intake of a 1.0\% TIMEx-supplemented diet increased the liver mass of the wildtype mice (Table 1), which might imply the development of hepatomegaly because of non-alcoholic fatty liver disease [26]. If this were true, hepatic fat accumulation would be associated with high circulating ALT and AST activities, which have been identified in individuals at risk of liver disease [27]. However, there were no differences in the activities 
in the wild-type mice consuming $0 \%, 0.1 \%$, or $1.0 \%$ TIMEx-containing diets (Figure 1e,f). Therefore, we concluded that this effect was sporadic, but not toxic.

The daily consumption of TIMEx for 8 weeks significantly reduced the serum triglyceride concentration of $\mathrm{ApoE}^{-/-}$mice, but not that of total cholesterol (Figure 1a). The effect on triglyceride was dose-dependent, with the effect of $1.0 \%$-supplementation of the diet being significant. This effect was not the result of malnutrition, because there were no differences in food intake (Table 1) or serum albumin concentration (Figure 1d), which are used as markers of nutritional status, between the groups [28]. On the other hand, the hepatic triglyceride and total cholesterol levels were not affected by the consumption of TIMEx (Figure 2). The appropriate level of supplementation for animals cannot be extrapolated to determine a human equivalent dose on the basis of body mass alone. Instead, body surface area (BSA; $\mathrm{mg} / \mathrm{m}^{2}$ ) is used to convert an animal dose to the equivalent human dose. The dose is multiplied by the $\mathrm{Km}$ values of 37 for adult humans and 3 for mice in order to convert a dose in $\mathrm{mg} / \mathrm{kg}$ to a dose in $\mathrm{mg} / \mathrm{m}^{2}$ [29], and calculated using the following formula:

$$
\text { Human equivalent dose }(\mathrm{mg} / \mathrm{kg})=\text { Mouse dose }(\mathrm{mg} / \mathrm{kg}) \times \frac{\text { Mouse } \mathrm{Km}(3)}{\operatorname{Human~Km~(37)}}
$$

In the present study, the 1.0\% TIMEx-supplemented group, in which final body mass was $28.1 \pm 0.8 \mathrm{~g}$, consumed $28.6 \mathrm{mg}$ TIMEx per day (Table 1 ), equivalent to a daily consumption of TIMEx of $1000 \mathrm{mg} / \mathrm{kg}$ body mass in mice. This dose is equivalent to $81.1 \mathrm{mg}$ TIMEx / $\mathrm{kg}$ body mass/day for humans, which equates to a $4860 \mathrm{mg}$ dose for a $60 \mathrm{~kg}$ person. More detailed studies, particularly human trials, should be undertaken in the future.

TIMEx consumption did not affect the serum triglyceride concentration of wild-type mice. In a previous study, 90 days of TIMEx administration tended to reduce serum triglyceride in rats at a dose of $2500 \mathrm{mg} / \mathrm{kg} /$ day, although this effect was not significant [16]. In the present study, wild-type mice in the $1.0 \%$ group consumed daily $27.7 \mathrm{mg} / \mathrm{mouse}$ (955 mg/ $\mathrm{kg}$ body mass) TIMEx (Table 1), indicating that the daily consumption of a larger amount of TIMEx might have a more marked effect on serum triglyceride in wild-type mice. Thus, the present data suggest that the daily consumption of $4860 \mathrm{mg}$ TIMEx by adult humans would help prevent hypertriglyceridemia but would have a less marked effect under normal conditions. TIMEx used in this study was prepared by hot-water extraction of thinned immature mangos according to the green tea preparation method as described in the following Section 4.2.2. For human applications, we propose to consume the decoction of dried thinned immature mango powder. Fruit acidity of mango is attributed mainly to the concentration of citric acid [8]. Its amount is high in immature stage (ca. $1000 \mathrm{mg} / 100$ fresh weight), and dramatically decrease during ripening process (ca. $100 \mathrm{mg} / 100 \mathrm{~g}$ fresh weight) [30]. Hence, the point to be paid attention is the strong and characteristic acidity.

An increase in LDL, which carries cholesterol in the circulation, provokes lipid accumulation in the vascular wall and plays a pivotal role in the progression of atherosclerosis [31]. Therefore, the daily consumption of food materials, such as walnuts, which reduce serum cholesterol and triglyceride concentrations, has been reported to reduce the atherosclerotic plaque area in $\mathrm{ApoE}^{-/-}$mice [32]. However, even 1.0\% TIMEx consumption for 8 weeks did not affect plaque area in the present study (Figure $3 b$ ). This implies that the daily consumption of TIMEx prevents hypertriglyceridemia, but not hypercholesterolemia, and therefore might not prevent atherosclerosis.

We also measured the concentrations of several hormones that regulate lipid homeostasis to better understand the effects of dietary TIMEx supplementation in $\mathrm{ApoE}^{-/-}$mice. Resistin is produced by adipose tissue, and a high circulating concentration of resistin is associated with a higher risk of atherosclerosis $[17,18]$. Leptin is a hormone that is exclusively secreted by adipocytes, and its expression positively correlates with obesity [20]. GIP, which is secreted by enteroendocrine K-cells, has been reported to be implied in the development of obesity and the pathogenesis of cardiovascular disease [19]. Daily consumption of a $1.0 \%$ TIMEx-supplemented diet for 8 weeks significantly reduced the circulating resistin 
concentration in $\mathrm{ApoE}^{-/-}$mice, and the concentrations of both leptin and GIP were also much lower (Figure $4 \mathrm{a}-\mathrm{c}$ ). The downregulation of these three hormones may be involved in the effect of TIMEx to prevent hypertriglyceridemia, but more detailed studies of the underlining mechanism of action should be undertaken in the future.

Recent studies have indicated that the gut microbes can impact host metabolism via signaling pathways in the gut, with effects on deposition of energy in fat stores, and consequently involves in both onset and progression of metabolic syndrome, including dyslipidemia and obesity [33-35]. Therefore, daily consumption of probiotics has been recognized to be a promising gut microbiota-targeted method for hyperlipidemia and atherosclerosis [36]. Some food materials and ingredients, such as Luffa cylindrica (L.) Roem, Cordyceps militaris, buckwheat and perilla oil, exert a potential dietary intervention strategy against obesity and dyslipidemia through modulating the gut microbiota [37-40]. Supplementation of mango pulp improves high-fat diet modulated gut microbiota [41]. Dietary fiber is major ingredient of mango (ca. $10 \mathrm{~g} / 100 \mathrm{~g}$ of dry weight) with balance of soluble and insoluble [42]. Daily treatment of pectin, which is one of the major watersoluble dietary fiber in mango [8], exhibits improvements in intestinal microbiota and lipid metabolism in mice consumed high-fat diet [43]. Although information about bioactive compounds in thinned immature mangos have not been well elucidated yet, pectin levels are reported to be decreased during the ripening [11]. These observations indicate the possibility that one of major active ingredients for amelioration of hypertriglyceridemia might be pectin via regulation of gut microbiota. Additional candidate is mangiferin, which is rich-in mango pulp and reported to protect hyperlipidemia through the regulation of metabolic pathways including metabolism of dicarboxylate, reduction of apoptosis, and $\beta$-cell regeneration including glucose transporter 2 (Glut-2) [44,45].

In recent years, more attention has been paid to non-communicable diseases (NCDs), which cover many entities including cancers, type 2 diabetes and cardiovascular diseases, because of their high leading cause of death worldwide [46]. Widespread obesity and abdominal fat accumulation are a major public health problem because of its association with NCDs $[47,48]$. Our data also imply that daily consumption of TIMEx can impact the other NCDs via regulating of blood lipid levels.

\section{Materials and Methods}

\subsection{Chemicals}

Cellulose, $\alpha$ - and $\beta$-cornstarch, and sucrose were purchased from Oriental Yeast Co., Ltd. (Tokyo, Japan). t-Butylhydroquinone, casein, L-cystine, and soybean oil were from Wako Pure Chemical Industries, Ltd. (Osaka, Japan). The lard, mineral mixture (AIN-93MMix), and vitamin mixture (AIN-93-VX) were purchased from MP Biomedicals, LLC (Irvine, CA, USA). All other reagents were of the highest grade available.

\subsection{Experimental Materials and Preparations}

\subsubsection{Immature Mango Fruits}

Immature Irwin mango fruits grown in Miyazaki, Japan, were collected by hand between the middle of February and the end of March 2018. After taxonomically identification on the basis of morphological characteristics by Mr. Kenta Hidaka (Star-Fruits Company, Ltd., Miyazaki, Japan), they were harvested under the following condition: the weight and size of individual fruits were $<25 \mathrm{~g}$ and $<\Phi 3 \mathrm{~cm}$. The fresh samples were immediately transported to the laboratory, and hand-washed with tap water to remove dirt and dust. The cleaned whole fruits including peel, flesh and seed were rapidly frozen in liquid nitrogen, and then lyophilized using a freeze dryer (Dura-Top MP \& Dura Dry MP, FTS SYSTEMS Ltd., Stone Ridge, NY, USA). Thinned immature mango were powdered using a Knife mill grindomix GM 200 (Verder Scientific Co., Tokyo, Japan), and stored away from light at $4{ }^{\circ} \mathrm{C}$ until extraction. 


\subsubsection{Hot-Water Extraction}

Extraction method was conducted according to the modified method for making the hot-water extract from green tea leaf [49]. In brief, thinned immature mango powder was mixed with ten volumes of hot water at $95{ }^{\circ} \mathrm{C}$ for 10 min with gently agitation. After centrifugation at $3000 \mathrm{rpm}$ for $10 \mathrm{~min}$, the supernatant was further filtrated with Whatman Grade GF/D Glass Microfiber Prefilters (Whatman, UK), and then lyophilized using the freeze dryer. The mango powder yield was ca. $26 \%$. The lyophilized powder of hotwater extract from thinned immature mango (TIMEx) was stored at $4{ }^{\circ} \mathrm{C}$ until used in animal experiments.

\subsection{Animal Experiments}

4.3.1. Institutional Approval of the Study Protocol

All animal procedures were approved by the Institutional Animal Care and Use Committee of the University of Miyazaki (No. 2018-027). This study was conducted in accordance with the Japanese Law for the Humane Treatment and Management of Animals (Law No. 105, 1973), which defines animal experimentation as the use of animals for scientific purposes and takes the 3Rs into consideration.

\subsubsection{Animal Housing, Diet, and Experiments}

Male BALB/c. KOR/StmSlc-Apoeshl $\left(\mathrm{ApoE}^{-/-}\right)$mice and their corresponding wildtype male BALB/c. (ApoE ${ }^{+/+}$) mice (both 7 weeks old) were obtained from Japan SLC (Shizuoka, Japan). The animals were housed three per cage (width $235 \mathrm{~mm} \times$ depth $165 \mathrm{~mm}$ $\times$ height $125 \mathrm{~mm}$ ) in an air-conditioned animal housing room (temperature: $23 \pm 2{ }^{\circ} \mathrm{C}$; humidity: $55 \pm 5 \%$ ) under a 12-h dark/light cycle (light period: 9:00 AM to 9:00 PM), with free access to tap water and powdered AIN-93M diet (Table 2).

After 1-week acclimation, the $\mathrm{ApoE}^{-/-}$and wild-type mice, respectively, were individually divided into two groups according to the modified methods reported by Hoang et al. [50]. The first group consumed a control diet ( $0 \%$ TIMEx), which was the modified AIN-93M based diet containing a $20 \%$ fat. The second groups consumed control diet containing $0.1 \%$ TIMEx or $1.0 \%$ TIMEx (Table 2 ). After 8 -weeks consumption, blood sample was drawn from the abdominal vein under anesthesia with isoflurane $(1.5 \%)$ without fasting and put into serum Capiject tubes (Terumo Medical Corporation, Somerset, NJ, USA). Following $30 \mathrm{~min}$ standing at room temperature, serum fraction was separated by centrifugation at $3500 \times g$ for $90 \mathrm{~s}$ and was stored at $-80{ }^{\circ} \mathrm{C}$ until analysis. The organs including liver, kidney, spleen, and visceral fats (epididymal fat + perirenal fat) were weighed. Liver section was stored at $-80^{\circ} \mathrm{C}$ for lipid analysis after freezing in liquid nitrogen.

\subsubsection{Quantification of Atherosclerotic Lesions}

Atherosclerotic lesion was assessed in the aortas using the modified methods of previous reports [51,52]. Briefly, after removing the organs listed above, mice were perfused with phosphate-buffered saline. The entire aorta was dissected from the proximal ascending aorta to the bifurcation of the iliac artery under a dissecting microscope (Stemi 305 cam, Carl Zeiss Microscopy GmbH, München, Germany). Adventitial fats were removed, and the aorta was opened longitudinally and pinned flat onto a silicon board. After fixing with $4 \%$ paraformaldehyde, the aortas were stained using Oil Red O. The staining aortas were photographed using a 1.2 mega pixel camera (Stemi $305 \mathrm{cam}$ ). The photographs were digitized, and total aortic areas and atherosclerotic lesion areas were calculated using Image J (V. 1.44p, NIH, Bethesda, MD, USA). The results were indicated as a percentage of the thoracic aortic area that contained lesions. This operation, including calculation were carried out by observers not informed about the kind of treatment each animal had received. 


\subsubsection{Blood Chemistry and Adipokines}

Serum biochemical parameters (triglycerides, total cholesterol, glucose, albumin, AST and ALT) were analyzed using a Dri-Chem 4000v chemistry analyzer (Fujifilm Co., Tokyo, Japan) with an individual cartridge slide. The serum resistin, leptin, glucose-dependent insulinotropic polypeptide (GIP), insulin, amylin and glucagon-like peptide-1 (GLP-1) levels were analyzed using an MMHMAG-44 Mouse Metabolic Hormone Panel multiplex biometric enzyme-linked immunosorbent assay (Millipore, Billerica, MA, USA) according to the manufacturer's instructions.

\subsubsection{Hepatic Lipid Analysis}

Hepatic lipids were extracted according to our previous method [53]. Briefly, after $200 \mathrm{mg}$ aliquots of liver samples were homogenized with $1 \mathrm{~mL}$ of $50 \mathrm{mM}$ sodium acetate, $6 \mathrm{~mL}$ chloroform-methanol $(2: 1$ [vol/vol] $)$ was added, and the mixture incubated at $40{ }^{\circ} \mathrm{C}$ for $30 \mathrm{~min}$. An aliquot of the organic phase $(500 \mu \mathrm{L})$ was dried with a centrifugal concentrator (CC-105; Tomy Seiko Co., Ltd., Tokyo, Japan), and the residues were dissolved in $200 \mu \mathrm{L}$ of $10 \%$ Triton X-100 containing isopropyl alcohol. Triglycerides, total cholesterol, and phospholipid levels were analyzed using individual test kits obtained from Wako Pure Chemical Industries, Ltd.

\subsection{Statistical Analysis}

Data are presented as the mean \pm standard error of the mean (SEM). Statistical analyses were conducted using both software, Pharmaco ANOVA (ver. 1) (Scientist Press Co., Ltd., Tokyo, Japan) and Pharmaco Basic (ver. 16) (Scientist Press Co., Ltd.). Statistical significance against individual control diet ( $\%$ TIMEx) group was determined using one-way analysis of variance (ANOVA), followed by the Williams' multiple comparison test as post-hoc test. To make comparisons within the groups, alpha value was set to 0.05 .

\section{Conclusions}

In this study, we have determined whether TIMEx consumption protects against dyslipidemia, including hypertriglyceridemia and hypercholesterolemia, in $\mathrm{ApoE}^{-/-}$ mice. Our data show that the daily consumption of a 1.0\% TIMEx-supplemented diet for 8 weeks prevents hypertriglyceridemia but not hypercholesterolemia in $\mathrm{ApoE}^{-/-}$mice. However, this effect is less noticeable under normal conditions in wild-type mice. Lower concentrations of resistin, leptin, and GIP may mediate this effect. These findings imply that TIMEx is a novel candidate of functional foods. The next logical step should be undertaken in the future, particularly on the mechanism of action, as well as human trials.

Author Contributions: Conceptualization, H.S. and T.S.; methodology, H.S.; resources, K.H. and T.S.; software, H.T.; validation, H.T., W.T. and H.S.; formal analysis, H.T.; investigation, H.T., W.T., H.M. and D.Y.; data curation, H.T. and W.T. and H.S.; writing-original draft preparation, H.T.; writing-review and editing, H.S.; project administration, H.S.; funding acquisition, H.S. All authors have read and agreed to the published version of the manuscript.

Funding: This research was funded by the Japan Society for the Promotion of Science KAKENHI, grant numbers $16 \mathrm{H} 03040$ and $21 \mathrm{H} 03361$.

Institutional Review Board Statement: The study was conducted according to the guidelines of Japanese Law for the Humane Treatment and Management of Animals (Law No. 105, 1973) and approved by the Institutional Animal Care and Use Committee of the University of Miyazaki, Japan (protocol code No. 2018-027 and date of approval: 18 October 2018).

Informed Consent Statement: Not applicable.

Data Availability Statement: No new data were created or analyzed in this study. Data sharing is not applicable to this article.

Acknowledgments: We thank Kaede Hidaka for her significant contributions to carry out this study. We also thank former Masanobu Sakono (University of Miyazaki, Japan) and Yasushi Matsuura 
(Miyazaki Prefectural Food Research and Development Center, Japan) for their contribution for the preparation of TIMEx.

Conflicts of Interest: The authors declare no conflict of interest.

\section{References}

1. Wu, L.; Parhofer, K.G. Diabetic dyslipidemia. Metabolism 2014, 63, 1469-1479. [CrossRef] [PubMed]

2. Fras, Z.; Jug, B.; Penson, P.E.; Rizzo, M. Challenges and opportunities on lipid metabolism disorders diagnosis and therapy: Novel insights and future perspective. Metabolites 2021, 11, 611. [CrossRef] [PubMed]

3. Banach, M.; Penson, P.E.; Vrablik, M.; Bunc, M.; Dyrbus, K.; Fedacko, J.; Gaita, D.; Gierlotka, M.; Jarai, Z.; Magda, S.L.; et al. Optimal use of lipid-lowering therapy after acute coronary syndromes: A position paper endorsed by the International Lipid Expert Panel (ILEP). Pharmacol Res. 2021, 166, 105499. [CrossRef] [PubMed]

4. Fernandes Silva, L.; Vangipurapu, J.; Laakso, M. The "Common Soil Hypothesis" revisited-risk factors for type 2 diabetes and cardiovascular disease. Metabolites 2021, 11, 691. [CrossRef] [PubMed]

5. Nuthikattu, S.; Milenkovic, D.; Rutledge, J.; Villablanca, A. The western diet regulates hippocampal microvascular gene expression: An integrated genomic analyses in female mice. Sci. Rep. 2019, 9, 19058. [CrossRef]

6. Food and Agriculture Organization of the United Nations. Major Tropical Fruits-Market Review. Available online: https: / / www.fao.org/3/ca5692en/ca5692en.pdf (accessed on 15 January 2022).

7. Food and Agriculture Orgnization of the United Nations. Post-Harvest Management of Mango for Quality and Safety Assurance. Available online: https:/ / www.fao.org/3/I8239EN/i8239en.pdf (accessed on 15 January 2022).

8. Maldonado-Celis, M.E.; Yahia, E.M.; Bedoya, R.; Landazuri, P.; Loango, N.; Aguillon, J.; Restrepo, B.; Guerrero Ospina, J.C. Chemical composition of mango (Mangifera indica L.) fruit: Nutritional and phytochemical compounds. Front. Plant. Sci. 2019, 10, 1073. [CrossRef]

9. Smith, J.C.; Biasi, W.V.; Holstege, D.; Mitcham, E.J. Effect of passive drying on ascorbic acid, alpha-tocopherol, and beta-carotene in tomato and mango. J. Food Sci. 2018, 83, 1412-1421. [CrossRef]

10. Qi, J.; Li, K.; Shi, Y.; Li, Y.; Dong, L.; Liu, L.; Li, M.; Ren, H.; Liu, X.; Fang, C.; et al. Cross-species comparison of metabolomics to decipher the metabolic diversity in ten fruits. Metabolites 2021, 11, 164. [CrossRef]

11. Lebaka, V.R.; Wee, Y.J.; Ye, W.; Korivi, M. Nutritional composition and bioactive compounds in three different parts of mango fruit. Int. J. Environ. Res. Public Health 2021, 18, 741. [CrossRef]

12. Burge, G.K.; Spence, C.B.; Marshall, R.R. Kiwifruit: Effects of thinning on fruit size, vegetative growth, and return bloom. N. Z. J. Exp. Agric. 1987, 151, 317-324. [CrossRef]

13. Elfving, D.C.; Schechter, I. Fruit count, fruit weight, and yield relationships in 'Delicious' apple trees on nine rootstock. HortScience 1993, 28, 793-795. [CrossRef]

14. Yeshitela, T.; Robbertse, P.J.; Fivas, J. Effects of fruit thinning on 'Sensation' mango (Mangifera indica) trees with respect to fruit quantity, quality and tree phenology. Expl. Agric. 2004, 40, 433-444. [CrossRef]

15. National Mango Board. Mango Handling and Ripening Protocol. Available online: https://www.mango.org/wp-content/ uploads/2017/10/Mango_Handling_and_Ripening_Protocol_Eng.pdf (accessed on 15 January 2022).

16. Tajiri, H.; Tanaka, W.; Takashima, M.; Matsuyama, H.; Sugita, T.; Hidaka, K.; Sakakibara, H. Subchronic safety evaluation of hot-water extract from thinned immature mangos (Mangifera indica 'Irwin'): 90-days oral toxicity study in rats. Toxicol. Rep. 2021, 8, 1046-1053. [CrossRef] [PubMed]

17. Cao, H. Adipocytokines in obesity and metabolic disease. J. Endocrinol. 2014, 220, T47-T59. [CrossRef]

18. Farkhondeh, T.; Llorens, S.; Pourbagher-Shahri, A.M.; Ashrafizadeh, M.; Talebi, M.; Shakibaei, M.; Samarghandian, S. An overview of the role of adipokines in cardiometabolic diseases. Molecules 2020, 25, 5218. [CrossRef]

19. Heimburger, S.M.; Bergmann, N.C.; Augustin, R.; Gasbjerg, L.S.; Christensen, M.B.; Knop, F.K. Glucose-dependent insulinotropic polypeptide (GIP) and cardiovascular disease. Peptides 2020, 125, 170174. [CrossRef]

20. Yamashita, K.; Yatsuya, H.; Muramatsu, T.; Toyoshima, H.; Murohara, T.; Tamakoshi, K. Association of coffee consumption with serum adiponectin, leptin, inflammation and metabolic markers in Japanese workers: A cross-sectional study. Nutr Diabetes 2012, 2, e33. [CrossRef]

21. Mahley, R.W. Apolipoprotein E: From cardiovascular disease to neurodegenerative disorders. J. Mol. Med. 2016, 94, 739-746. [CrossRef]

22. Krishnan, M.; Hwang, J.S.; Kim, M.; Kim, Y.J.; Seo, J.H.H.; Jung, J.; Ha, E. Beta-hydroxybutyrate impedes the progression of alzheimer's disease and atherosclerosis in ApoE-deficient mice. Nutrients 2020, 12, 471. [CrossRef]

23. Emini Veseli, B.; Perrotta, P.; De Meyer, G.R.A.; Roth, L.; Van der Donckt, C.; Martinet, W.; De Meyer, G.R.Y. Animal models of atherosclerosis. Eur. J. Pharm. 2017, 816, 3-13. [CrossRef]

24. Han, B.H.; Seo, C.S.; Yoon, J.J.; Kim, H.Y.; Ahn, Y.M.; Eun, S.Y.; Hong, M.H.; Lee, J.G.; Shin, H.K.; Lee, H.S.; et al. The inhibitory effect of ojeoksan on early and advanced atherosclerosis. Nutrients 2018, 10, 1256. [CrossRef] [PubMed] 
25. Matsuyama, H.; Tanaka, W.; Miyoshi, N.; Miyazaki, T.; Michimoto, H.; Sakakibara, H. Beneficial effects of the consumption of sun-dried radishes (Raphanus sativus cv. YR-Hyuga-Risou) on dyslipidemia in apolipoprotein E-deficient mice. J. Food Biochem. 2021, 45, e13727. [CrossRef]

26. Angulo, P.; Lindor, K.D. Non-alcoholic fatty liver disease. J. Gastroenterol. Hepatol. 2002, 17, S186-S190. [CrossRef] [PubMed]

27. Wadhawan, M.; Anand, A.C. Coffee and liver disease. J. Clin. Exp. Hepatol. 2016, 6, 40-46. [CrossRef] [PubMed]

28. Keller, U. Nutritional laboratory markers in malnutrition. J. Clin. Med. 2019, 8, 775. [CrossRef] [PubMed]

29. Reagan-Shaw, S.; Nihal, M.; Ahmad, N. Dose translation from animal to human studies revisited. FASEB J. 2008, $22,659-661$. [CrossRef]

30. Yasunaga, E.; Fukuda, S.; Takata, D.; Spreer, W.; Sardsud, V.; Nakano, K. Quality changes in fresh mango fruits (Mangifera indica L. 'Nam Dok Mai') under actual distribution temperature profile from Thailand to Japan. Environ. Control. Biol. 2018, 56, 45-49. [CrossRef]

31. Libby, P.; Buring, J.E.; Badimon, L.; Hansson, G.K.; Deanfield, J.; Bittencourt, M.S.; Tokgozoglu, L.; Lewis, E.F. Atherosclerosis Nat. Rev. Dis. Primers 2019, 5, 56. [CrossRef]

32. Nergiz-Unal, R.; Kuijpers, M.J.; de Witt, S.M.; Heeneman, S.; Feijge, M.A.; Garcia Caraballo, S.C.; Biessen, E.A.; Haenen, G.R.; Cosemans, J.M.; Heemskerk, J.W. Atheroprotective effect of dietary walnut intake in ApoE-deficient mice: Involvement of lipids and coagulation factors. Thromb. Res. 2013, 131, 411-417. [CrossRef]

33. Li, J.; Lin, S.; Vanhoutte, P.M.; Woo, C.W.; Xu, A. Ak.kkermansia muciniphila protects gainst therosclerosis by preventing metabolic endotoxemia-induced inflammation in Apoe ${ }^{-/-}$mice. Circulation 2016, 133, 2434-2446. [CrossRef]

34. Ley, R.E. Obesity and the human microbiome. Curr. Opin. Gastroenterol. 2010, 26, 5-11. [CrossRef] [PubMed]

35. Vijay-Kumar, M.; Aitken, J.D.; Carvalho, F.A.; Cullender, T.C.; Mwangi, S.; Srinivasan, S.; Sitaraman, S.V.; Knight, R.; Ley, R.E.; Gewirtz, A.T. Metabolic syndrome and altered gut microbiota in mice lacking Toll-like receptor 5. Science 2010, 328, 228-231. [CrossRef] [PubMed]

36. Jiang, T.; Wu, H.; Yang, X.; Li, Y.; Zhang, Z.; Chen, F.; Zhao, L.; Zhang, C. Lactobacillus mucosae strain promoted by a highfiber diet in genetic obese child alleviates lipid metabolism and modifies gut microbiota in ApoE ${ }^{(-/-)}$mice on a western diet. Microorganisms 2020, 8, 1225. [CrossRef]

37. Zhang, L.; Shi, M.; Ji, J.; Hu, X.; Chen, F. Gut microbiota determines the prevention effects of Luffa cylindrica (L.) Roem supplementation against obesity and associated metabolic disorders induced by high-fat diet. FASEB J. 2019, 33, 10339-10352. [CrossRef]

38. Zhou, X.L.; Yan, B.B.; Xiao, Y.; Zhou, Y.M.; Liu, T.Y. Tartary buckwheat protein prevented dyslipidemia in high-fat diet-fed mice associated with gut microbiota changes. Food Chem. Toxicol. 2018, 119, 296-301. [CrossRef] [PubMed]

39. Yu, M.; Yue, J.; Hui, N.; Zhi, Y.; Hayat, K.; Yang, X.; Zhang, D.; Chu, S.; Zhou, P. Anti-hyperlipidemia and gut microbiota community regulation effects of selenium-rich cordyceps militaris polysaccharides on the high-fat diet-fed mice model. Foods 2021, 10, 2252. [CrossRef]

40. Wang, F.; Zhu, H.; Hu, M.; Wang, J.; Xia, H.; Yang, X.; Yang, L.; Sun, G. Perilla oil supplementation improves hypertriglyceridemia and gut dysbiosis in diabetic KKAy mice. Mol. Nutr. Food Res. 2018, 62, e1800299. [CrossRef]

41. Ojo, B.; El-Rassi, G.D.; Payton, M.E.; Perkins-Veazie, P.; Clarke, S.; Smith, B.J.; Lucas, E.A. Mango supplementation modulates gut microbial dysbiosis and short-chain fatty acid production independent of body weight reduction in C57BL/6 mice fed a high-fat diet. J. Nutr. 2016, 146, 1483-1491. [CrossRef]

42. Chang, S.C.; Lee, M.S.; Lin, C.J.; Chen, M.L. Dietary fiber content and composition of fruits in Taiwan. Asia Pac. J. Clin. Nutr. 1998, 7, 206-210.

43. Li, W.; Zhang, K.; Yang, H. Pectin alleviates high fat (lard) diet-induced nonalcoholic fatty liver disease in mice: Possible role of short-chain fatty acids and gut microbiota regulated by pectin. J. Agric. Food Chem. 2018, 66, 8015-8025. [CrossRef]

44. Imran, M.; Arshad, M.S.; Butt, M.S.; Kwon, J.H.; Arshad, M.U.; Sultan, M.T. Mangiferin: A natural miracle bioactive compound against lifestyle related disorders. Lipids Health Dis. 2017, 16, 84. [CrossRef] [PubMed]

45. Wang, H.L.; Li, C.Y.; Zhang, B.; Liu, Y.D.; Lu, B.M.; Shi, Z.; An, N.; Zhao, L.K.; Zhang, J.J.; Bao, J.K.; et al. Mangiferin facilitates islet regeneration and beta-cell proliferation through upregulation of cell cycle and beta-cell regeneration regulators. Int. J. Mol. Sci. 2014, 15, 9016-9035. [CrossRef]

46. Hegelund, M.H.; Faurholt-Jepsen, D.; Bygbjerg, I.C. Prevention of opportunistic non-communicable diseases. Int. Health 2020, 12, 1-2. [CrossRef] [PubMed]

47. Estruch, R.; Ros, E. The role of the Mediterranean diet on weight loss and obesity-related diseases. Rev. Endocr. Metab. Disord. 2020, 21, 315-327. [CrossRef] [PubMed]

48. Dhawan, D.; Sharma, S. Abdominal obesity, adipokines and non-communicable diseases. J. Steroid Biochem. Mol. Biol. 2020, 203, 105737. [CrossRef] [PubMed]

49. Lin, S.D.; Liang, C.H.; Liu, E.H.; Mau, J.L. Antioxidant properties of water extracts from parchinng green tea. J. Food Biochem. 2010, 34, 477-500. [CrossRef]

50. Hoang, M.H.; Jia, Y.; Mok, B.; Jun, H.J.; Hwang, K.Y.; Lee, S.J. Kaempferol ameliorates symptoms of metabolic syndrome by regulating activities of liver $\mathrm{X}$ receptor-beta. J. Nutr. Biochem. 2015, 26, 868-875. [CrossRef]

51. Matsumoto, M.; Sata, M.; Fukuda, D.; Tanaka, K.; Soma, M.; Hirata, Y.; Nagai, R. Orally administered eicosapentaenoic acid reduces and stabilizes atherosclerotic lesions in ApoE-deficient mice. Atherosclerosis 2008, 197, 524-533. [CrossRef] 
52. Tang, S.L.; Zhao, Z.W.; Liu, S.M.; Wang, G.; Yu, X.H.; Zou, J.; Wang, S.Q.; Dai, X.Y.; Fu, M.G.; Zheng, X.L.; et al. Pregnancyassociated plasma protein-A accelerates atherosclerosis by regulating reverse cholesterol transport and inflammation. Circ. J. 2019, 83, 515-523. [CrossRef]

53. Yokoyama, D.; Tanaka, W.; Hashizume, Y.; Tandia, M.; Sakono, M.; Shimoi, K.; Sakakibara, H. Daily consumption of monoglucosylrutin prevents high-fat diet-induced obesity by suppressing gastric inhibitory polypeptide secretion in mice. Funct. Foods Health. Dis. 2018, 8, 353-371. [CrossRef] 